Пилипчук Ю. В.;

Яровий В. С.;

Цимбал I. В.;

Троцько Л. Г.;

Жовтун А. А.

Науковий центр зв’язку та інформатизації Військового інституту телекомунікацій та інформатизації імені Героїв Крут, Київ

\title{
Аналіз стану метрологічного забезпечення збройних сил провідних країн світу
}

Резюме. У статті проведено аналіз стану метрологічного забезпечення, який існує в арміях провідних країн світу. Наведено приклади систем метрологічного забезпечення провідних країн світу. 3 проведеного аналізу зроблені висновки щодо удосконалення системи метрологічного забезпечення Збройних Сил України.

Ключові слова: системи метрологічного забезпечення; метрологічні лабораторії; військова метрологічна база.

Постановка проблеми. У Збройних Силах України метрологічне забезпечення військ формувалося на основі розроблених радянських підходів, і меншою мірою на основі ситуативно запозичених елементів окремих держав НАТО. Це призводить до низки недоліків у функціонуванні метрологічного забезпечення Збройних Сил, а саме: відсутності документації 3 технічного обслуговування новітніх засобів зв'язку 3 детальним алгоритмом проведення вимірювання параметрів, неукомплектованості окремих військових частин та установ засобами вимірювальної техніки необхідних для проведення вимірювань та контролю параметрів новітніх засобів зв'язку та ін. [1]. Для визначення пріоритетних напрямів розвитку метрологічного забезпечення Збройних Сил України та подолання існуючих недоліків доцільно провести аналіз метрологічного забезпечення провідних країн світу та виявити наскільки закордонний досвід в організації метрологічного забезпечення може допомогти у розв'язанні зазначених проблем.

Аналіз останніх досліджень i публікацій. Існує низка напрацювань, присвячених питанням оптимізації метрологічного забезпечення Збройних Сил України. В. Дзюба, С. Ковальчук, В. Рижаков, Л. Сакович розробили Керівництво з технічного забезпечення зв'язку та автоматизації управління військами Збройних Сил України [2]. У роботах М. Яковлева та Е. Рыжова проведено аналіз системи метрологічного обслуговування засобів зв'язку Сухопутних військ та визначено основні напрями іiі вдосконалення [3]. О. Морозовим розроблено математичну модель впливу метрологічного забезпечення на рівень готовності парку засобів вимірювання та розроблено низку методик і методичних підходів до розв'язання цього питання [4].

Проте у відкритих джерелах не систематизовано аналіз досвіду метрологічного забезпечення збройних сил інших країн.

Метою статті $\epsilon$ проведення аналізу стану метрологічного забезпечення, який існує в арміях провідних країн світу для надання рекомендацій щодо удосконалення сучасного стану системи метрологічного забезпечення Збройних Сил України.

Викладення основного матеріалу. Розглянемо системи метрологічного забезпечення Збройних Сил Республіки Польщі, Німеччини, США та Республіки Білорусь.

Система метрологічного забезпечення Збройних Сил Польщі.

Останнім часом у Війську Польському повністю завершено процес переходу до централізованої системи метрологічного забезпечення, яка функціонує за територіальним принципом [6]. Центральним органом 3 метрологічного забезпечення $\epsilon$ Військовий центр метрології (ВМЦ), на який покладено завдання 3 організації метрологічного забезпечення військових частин незалежно від їх підпорядкованості. Територія Польщі поділена на 6 регіонів, в яких знаходиться військова метрологічна база (ВМБ), підпорядкована ВЦМ. 
Склад військової метрологічної служби:

ВЦМ, м. Варшава, штатна чисельність 23 особи;

Центральна ВМБ, м. Варшава (філії в м. Зеленці та Комарово), штатна чисельність 138 осіб;

1 ВМБ, м. Гдиня, штатна чисельність 34 особи;

2 ВМБ, м. Бидгощ, штатна чисельність 80 осіб;

3 ВМБ, м. Вроцлав, (філія в м. Міліч) штатна чисельність - 44 особи;

4 ВМБ, м. Радом, штатна чисельність 52 особи;

- Спеціалізована ВМБ (метрологічне обслуговування літаків F-16), м. Познань, штатна чисельність - 46 осіб.

Метрологічне забезпечення військових підрозділів хімічної і радіаційної оборони виконують філія 3 ВМБ (Міліч) та філія Центральної ВМБ (Комарово).

Планування та контроль виробничої діяльності ВМБ виконується у ВМЦ 3 використанням спеціалізованих програмних засобів.

Протягом останніх років було здійснено повне технічне переоснащення військових метрологічних лабораторій. Основний принцип переоснащення - автоматизація вимірювань для досягнення максимальної продуктивності та нарощування виробничих можливостей. Зважаючи на те, що науково-технічний та виробничий потенціал Республіки Польща не забезпечує розроблення та створення вихідних ia робочих еталонів за більшістю фізичних величин, закупівлі підлягали еталони таких провідних виробників вимірювальної техніки, як "Hewlett Packard", "Rohde\&Shwarz", "Fluke" та інших.

Усі військові метрологічні лабораторії здійснюють свою діяльність відповідно до вимог міжнародних нормативних документів ISO 19011, ISO 9001, ISO/IEC 17025, що гарантує якість виконання робіт і надалі дає змогу на державному рівні спростити процедуру взаємного визнання результатів, отриманих у процесі метрологічної діяльності.

3 огляду на досвід метрологічного обслуговування миротворчого контингенту Війська Польського в Іраку, було відзначено, що метрологічне забезпечення миротворчого контингенту має значні ускладнення через труднощі доставки фахівців-метрологів та повірочного обладнання до місць проведення миротворчих операцій. Прийнято рішення надалі створювати обмінні фонди засобів вимірювальної техніки та здійснювати періодичну заміну приладів, що знаходяться в експлуатації у миротворчому контингенті та відкалібровані.

Прийняття на озброєння та закупівля нових високотехнологічних зразків ОВТ змушує вдосконалювати та нарощувати військову еталонну базу Війська Польського.

Промисловістю Республіки Польща розроблена та поставлена у Збройні Сили пересувна лабораторія вимірювальної техніки (ПЛВТ) “Transmet” контейнерного типу на базі трейлеру для буксування сідельним тягачем. ПЛВТ призначена для експлуатації в складних кліматичних умовах (від $-30^{\circ} \mathrm{C}$ до $\left.+40^{\circ} \mathrm{C}\right)$, має автономне джерело електроживлення (дизель-генератор та резервні акумуляторні батареї.

Лабораторія оснащена сучасною прецизійною вимірювальною технікою 3 високим рівнем автоматизації вимірювань, обладнана системою моніторингу та стабілізації електроживлення та мікроклімату, локальною обчислювальною мережею збору та зберігання даних 3 можливістю їх передавання через Internet, навігаційною системою GPS.

Організація системи метрологічного забезпечення призначена для:

надання послуг щодо метрологічного контролю вимірювальних приладів озброєння та військової техніки;

зменшення часу відсутності вимірювальних приладів у військових підрозділах до найнижчого рівню (крайній термін 14 днів);

досягнення необхідного рівня

боєготовності ОВТ (можливого максимуму) завдяки систематичній повірці приладів у військових підрозділах на базі реорганізованих пересувних лабораторій;

здійснення метрологічного нагляду в підрозділах, які обслуговуються MCLs відповідно до інспекторських повноважень, наданих Начальником військового метрологічного нагляду.

Завданнями військової метрології в галузі прийняття стандартів НАТО є:

надання інформації про міжнародні стандарти в галузі метрології, які $\epsilon$ обов'язковими в країнах НАТО, а також їх аналіз і прийняття (ISO, ISA, IEC, EN);

аналіз i прийняття процедур калібрування вимірювальних приладів, що $є$ обов'язковими в країнах НАТО;

надання інформації про зразкові засоби вимірювань, що використовуються в НАТО, та можливість їх порівняння з еталонами PSL 
(зокрема тими, які не належать Центральному офісу вимірювань);

забезпечення єдності зразкових засобів вимірювань ЗС Польщі $з$ їх аналогами країн HATO;

реалізація співробітництва метрологічних виконавчих органів у галузі взаємного визнання проведення перевірки калібрування та єдиних калібрувальних лабораторій;

проведення спільної підготовки щодо організації процедур базової та технічної метрології.

HATO:

У галузі співробітництва 3 країнами

на основі окремих угод налагодити співробітництво в галузі єдності зразкових засобів вимірювань ЗС Польщі з їх аналогами ЗС країн НАТО, зокрема, коли вони відсутні в управлінні вимірюваннями Польщі;

порівняння (міжлабораторні порівняння) зразкових засобів вимірювань ЗС Польщі з їх аналогами ЗС країн НАТО відповідно до окремих рішень;

стандартизація структури та якісної системи в калібрувальних лабораторіях 3С Польщі для налагодження зв'язку із ЗС країн НАТО (система військових калібрувальних лабораторій оцінки технічної компетенції призначена для визначення можливості взаємного визнання калібрування вимірювальних приладів);

прийняття калібрувальних процедур, що використовуються у ЗС Польщі відповідно до стандартів НАТО.

Система метрологічного забезпечення Збройних Сил Німеччини

Система метрологічного забезпечення Бундесверу $є$ підсистемою логістичного забезпечення Бундесверу [7].

Загальне керівництво метрологічним забезпеченням військ здійснює Головний штаб Інспекторату Бундесверу. Безпосереднє керівництво метрологічним забезпеченням військ здійснює Командування Сил Підтримки через такі логістичні органи:

калібрувальний Центр Бундесверу, який безпосередньо підпорядкований 47-му полку логістики оперативного командування;

підрозділ метрологічного забезпечення

Центру логістики Бундесверу;

підрозділ метрологічного забезпечення

Департаменту логістики Бундесверу.

Основні завдання покладені на Калібрувальний Центр Бундесверу:

калібрування та ремонт контрольновимірювальної техніки в стаціонарі та на виїзді; планування

забезпеченням контрольно-вимірювальною технікою (під керівництвом підрозділу метрологічного забезпечення Центру логістики Бундесверу);

упровадження управління системою якості за стандартом DIN EN ISO 9001;

обслуговування та вдосконалення програмного забезпечення для систем контролю стану спеціальних систем озброєння.

До складу Калібрувального Центру Бундесверу входять:

регіональна лабораторія I, Мехерніх, яка складається 3 калібрувальної лабораторії еталонів, калібрувальної лабораторії спеціальних систем озброєння;

регіональна лабораторія II, Шортенс; регіональна лабораторія III, Киль; регіональна лабораторія IV, Холоман; регіональна лабораторія $\mathrm{V}$, Кляйтинген; регіональна лабораторія VI, Котбус; відділ III програмування спеціальних систем озброєння.

До складу Калібрувального Центру Бундесверу входять 3 відділи:

1-й відділ калібрування, який складається із семи мобільних калібрувальних груп: дві групи електричних вимірювань; дві групи фізичних вимірювань; група спеціальної контрольно-вимірювальної техніки ВМС; група спеціальної контрольновимірювальної техніки ПС; група перевірки кисневого обладнання.

2-й відділ калібрування містить лабораторію еталонів; лабораторію спеціальних систем озброєння; шість регіональних лабораторій;

3-й відділ програмування спеціальних систем озброєння складається 3 відділення менеджменту програмним забезпеченням i відділення програмування.

Система метрологічного забезпечення Збройних Сил США.

Організацією, на яку в США покладена відповідальність за метрологічне забезпечення $є$ Національний інститут стандартів і метрології. NIST має такі функції: координує роботу суб'єктів метрологічної діяльності в галузі забезпечення єдності вимірювань;

забезпечує організацію участі в міжнародному співробітництві в галузі метрологічної діяльності;

сприяє впровадженню одиниць фізичних величин CI; 
виробляє рекомендації і правила застосування, ввезення та виготовлення засобів вимірювальної техніки;

захищає громадян i національну економіку від наслідків недостовірних результатів вимірювань;

координує наукові дослідження в галузі метрології тощо.

Цей інститут також здійснює загальну організацію метрологічного забезпечення в системі Міністерства оборони США.

Функції, подібні до функцій Національного інституту стандартів і метрології США, виконує низка інститутів в інших країнах - федеральна фізико-технічна організація (РТВ) в Німеччині, Національна лабораторія метрологій та випробувань (LNE) у Франції, Національна фізична лабораторія (Великобританія). Усі ці організації координують діяльність метрологічних структур у національних збройних силах.

Структура, що відповідає за метрологічне забезпечення в сухопутних військах США $є$ Department of the Army test, measurement, and diagnostic equipment (управління з випробувань, вимірювань та перевірки обладнання сухопутних військ США) - TMDE. Завданнями цього управління $\epsilon$ :

здійснення тестування, вимірювання та діагностики обладнання, калібрування та ремонт відповідно до затвердженого органу (AR 750-43);

забезпечення узгодження вимірювань i стандартів з NIST;

забезпечення калібрування та ремонту всіх армійських систем в усіх частинах світу де знаходяться сухопутні війська;

використовувати весь наявний інформаційний та інтелектуальний ресурс для забезпечення технічної підтримки метрологічних систем сухопутних військ США.

Управління, що виконують подібні функції існують в інших видах збройних сил США, які в США мають статус міністерств 3 власним бюджетом (наприклад, управління дослідження вимірювань сил спеціальних операцій при головному управлінні озброєння ВМС Збройних Сил США).

Система метрологічного забезпечення Збройних Сил Республіки Білорусь побудована за регіональним принципом. Вона подібна до системи метрологічного забезпечення Збройних Сил України побудованої за регіональновидовим принципом, але має такі особливості та відмінності [9]: а) структура метрологічної служби Збройних Сил Республіки Білорусь складається з таких елементів:

відділ метрологічного забезпечення, який входить до складу центрального апарату Міністерства оборони Республіки Білорусь підпорядкований заступнику Міністра оборони з озброєння;

начальники метрологічних служб оперативних командувань та ВійськовоПовітряних Сил;

139-й Центр метрологічного забезпечення (м. Мінськ), безпосередньо підпорядкований відділу метрологічного забезпечення;

1825-та База вимірювальної техніки (м. Борисів) Військово-Повітряних Сил та Протиповітряної оборони, до складу якої, крім метрологічних підрозділів, входять підрозділи 3 ремонту зенітно-ракетного озброєння та озброєння радіотехнічних військ;

штатні (позаштатні) начальники метрологічних служб в з'єднаннях (частинах); майстерні вимірювальної техніки в ремонтно-відновлювальних батальйонах; лабораторії (пункти) вимірювальної техніки в бригадах;

б) підготовка фахівців метрологічної служби тактичного рівня здійснюється в Російській Федерації (м. Вороніж), орієнтовно 2-3 фахівця на рік;

в) капітальний ремонт засобів вимірювальної техніки військового призначення не здійснюється через його економічну недоцільність. Існує лише три види ремонту засобів вимірювальної техніки поточний, відновлювальний, середній;

г) відділ метрологічного забезпечення $\epsilon$ довольчим органом лише для баз, майстерень та лабораторій вимірювальної техніки. Забезпечення засобами вимірювальної техніки військового призначення 3'єднань, частин та підрозділів здійснюється їх безпосередніми органами військового управління;

д) у бюджеті Міністерства оборони Республіки Білорусь $є$ окрема стаття для потреб метрологічного забезпечення, розпорядником якої $\epsilon$ начальник відділу метрологічного забезпечення.

Для ефективного обслуговування ОВТ у військових частинах Збройних Сил Республіки Білорусь функціонують групи регламенту та ремонту.

У структурі та на фондах метрологічних органів Збройних Сил Республіки Білорусь створені підмінні фонди засобів 
вимірювальної техніки та пересувні лабораторії вимірювальної техніки, що дає змогу оперативного розв'язання питання заміни вимірювальної техніки, що зі свого боку зменшує час оформлення документів під час експлуатації ОВТ.

Заходи метрологічного забезпечення військових формувань Збройних Сил Республіки Білорусь на рік здійснюються на підставі директиви начальника Генерального штабу Збройних Сил Республіки Білорусь.

$$
\text { У 139-му Центрі метрологічного }
$$

забезпечення (м. Мінськ) безпосереднього підпорядкування та 1825-й Базі вимірювальної техніки (м. Борисів) Військово-Повітряних Сил та Протиповітряної оборони, поряд з обліком вимірювальної техніки за допомогою книг та карток, заведений та ведеться електронний облік для оперативного формування звітності щодо наявності та визначення потреби у вимірювальній техніці.

Така організація метрологічного забезпечення дає можливість:

підтримувати високу якість та рівень метрологічного забезпечення для забезпечення необхідного рівня оперативної готовності ОВТ до виконання завдань; OBT;

забезпечення достовірності оцінки стану

забезпечення ефективного застосування вимірювальної техніки;

якісно планувати роботи 3 організації діяльності виїзних метрологічних групи;

завчасно вирішувати організаційні питання у військових частинах, які підлягають метрологічному обслуговуванню;

планувати та виділяти необхідні матеріально-технічні засоби, кошти для оплати витрат на відрядження та паливо-мастильні матеріали.

Висновки. Відповідно до проведеного аналізу метрологічного забезпечення низки держав спільним елементом більшості метрологічних служб $€$ ïx інкорпорація в загальнонаціональну систему стандартизації. В Україні згідно 3 керівними документами [10] метрологічна служба існує більш відокремлено від загальнонаціональної. У цьому контексті слід законодавчо i фактично затвердити положення про метрологічну службу Міністерства оборони та Збройних Сил України як частину загальнонаціональної.

Більшість систем метрологічного забезпечення проаналізованих країн мають подібну структуру, яка спирається на мережі територіальних вимірювальних підрозділів, що обслуговують види та роди збройних сил. В
Україні слід детальніше вивчити досвід запровадження таких підрозділів для ефективнішого забезпечення виконання метрологічних завдань.

Досвід Республіки Польща, яка переходить до стандартів НАТО засвідчив, що однією $з$ головних проблем цього переходу $\epsilon$ забезпечення метрологічних органів $\mathrm{i}$ підрозділів відповідними фахівцями. В Україні слід розглянути можливість щодо забезпечення процесу навчання таких.

\section{СПИСОК ВИКОРИСТАНОЇ ЛІТЕРАТУРИ}

1. Пилипчук Ю. В. та інші. Альтернативні способи вдосконалення метрологічного забезпечення сучасних засобів зв'язку [Електронний ресурс] // Режим доступу: file:///C:/Users/\%D0\%91\%D0\%BE\%D0\%B3\%D0\%B 4\%D0\%B0\%D0\%BD/Downloads/126117-269056-1PB.pdf

2. Керівництво 3 технічного забезпечення зв'язку та автоматизації управління військами Збройних Сил України / Дзюба В. М., Ковальчук Є. Д., Рижаков В. А., Сакович Л. М. і інші. - К.: Воєнне видавництво, 2003. $-259 \mathrm{c}$.

3. Анализ системы метрологического обслуживания средств связи Сухопутных войск и определение основных направлений ее усовершенствования М. Ю. Яковлев, Е. В. Рыжов, Стандартизація та метрологічне забезпечення ОВТ, Львів, 2012.Вип. 1(6)/2012. - С. 183-192,

4. Морозов О. О. Математична модель впливу метрологічного забезпечення на рівень готовності парку засобів вимірювання / О. О. Морозов // Открытые информационные и компьютерные интегрированные технологии. - Вып. 11.- 2002. C. $54-58$.

5. Біла книга 2017 Збройні Сили України [Текст] / [авт. тексту Експертна комісія Міністерства оборони України та Генерального штабу Збройних Сил України]. - К.: МО України, 2018. - 152 с.

6. Доповідь директора управління військового метрологічного нагляду Міністерства національної оборони Польщі Станіслава Дабровського, 2014 р.

7. Доповідь начальника відділення “Озброєння та експлуатація" 4.1 управління логістики Бундесвера підполковника Герхарда Міма, 2015 p.

8. Доповідь заступника начальника управління 3 випробувань, вимірювань та перевірки обладнання сухопутних військ США, 2014 p.

9. Доповідь начальника відділу метрологічного забезпечення Головного управління планування i координації технічного забезпечення Міністерства оборони Республіки Білорусь полковника Коновалова Д. А., 2013 рік.

10. Положення про метрологічну службу Міністерства оборони України та Збройних Сил України [Електронний ресурс] // Режим доступу: https://zakon.rada.gov.ua/rada/show/v0288322-17\#n10 
Пилипчук Ю. В.; Яровой В. С.; Цимбал І. В.;

Троцько Л. Г.; Жовтун А. А.

Научный центр связи и информатизации Военного института телекоммуникаций и информатизации имени Героев Крут, Киев

\section{мира \\ Анализ состояния метрологического обеспечения вооружённых сил ведущих стран}

Резюме. В статье проведен анализ состояния метрологического обеспечения, который существует в армиях ведущих стран мира. Проведены примеры систем метрологического обеспечения ведущих стран мира. Из этого анализа сформулированы выводы относительно усовершенствования метрологического обеспечения Вооруженных Сил Украины.

Ключевые слова: системы метрологического обеспечения; метрологические лаборатории; военная метрологическая база.

\section{Y. Pylypchuk; V. Yarovyi; I. Tsymbal;}

L. Trotsko; A. Zhovtun

Scientific Center for Communication and Informatization Military Institute of Telecommunications and Information Technologies the name of the Heroes of Kruty, Kyiv

Analysis of the state of metrological support that exists in the leading countries of the world

Resume. The statte analyzes the metrological support that exists in the armies of the leading countries of the world. Also presented are examples of metrological support systems of leading countries of the world. From this analysis, conclusions were made about the improvement of the methodological education of the Armed Forces of Ukraine .

Keywords: metrological assurance system; metrology laboratories; military metrology base. 